\title{
The Construction of the Psycho-sociological Knowledge on Diabetes Mellitus
}

\author{
Fabrycianne Goncalves Costa \\ Maria da Penha de Lima Coutinho ${ }^{1}$
}

${ }^{1}$ Universidade Federal da Paraíba, João Pessoa, PB

\begin{abstract}
This study aims to analyze the social representations elaborated by diabetic's people on diabetes mellitus and your treatment. The sample was composed of 80 participants with ages between 21 and 83 years old $(M=55.92, \mathrm{SD}=12.06)$, who answered to a sociodemographic questionnaire and the Word Association Test. The data were submitted to SPSS - 19.0 and Tri-deux-mots software and analyzed using descriptive statistics and factorial correspondence analysis. The results showed that the psychosocial knowledge construction of diabetes doesn't differ from scientific knowledge, while chronic disease, related to blood sugar problems, mood swing and life danger. The treatment, emerged associated as a food control, adherence and follow medical guidelines. It is hoped, that these results will contribute to enlarge the this disease visibility and with the therapeutic practices development in the context of diabetes, targeting both the physical and emotional aspects.
\end{abstract}

Keywords: Diabetes Mellitus; Social Representation; Psychosocial; Free Association.

\section{A Construção do Conhecimento Psicossociológico acerca do Diabetes Mellitus}

\section{Resumo}

Este estudo objetiva analisar as Representações Sociais (RS) elaboradas por pessoas diabéticas sobre o diabetes mellitus e seu tratamento. A amostra foi constituída por 80 participantes com idades entre 21 a 83 anos $(\mathrm{M}=55,92$; $\mathrm{DP}=12,06)$, que responderam a um questionário biossociodemográfico e à Técnica de Associação Livre de Palavras. Os dados foram computados pelos softwares SPSS - 19.0 e Tri-Deux-Mots e examinados por meio da estatística descritiva e análise fatorial de correspondência. Os resultados apontaram que a construção do conhecimento psicossociológico acerca do diabetes não difere do saber científico, pois foi representada enquanto doença crônica relacionada a problemas de açúcar no sangue, oscilação de humor e perigo de vida. As RS do tratamento emergiram de forma associada ao controle alimentar, manutenção e adesão às orientações médicas. Espera-se que esses resultados contribuam para uma maior visibilidade da doença e com a elaboração de práticas terapêuticas no contexto do diabetes, voltadas tanto para seus aspectos físicos, quanto emocionais.

Palavras-chave: Diabetes Mellitus; Representação Social; Psicossocial; Associação Livre.

\section{Construcción de Conocimiento Psico-sociológico sobre Diabetes Mellitus}

\begin{abstract}
Resumen
Este estudio tuvo como objetivo analizar las Representaciones Sociales (RS) elaboradas por personas diabéticas sobre Diabetes Mellitus y su tratamiento. La muestra fue constituída por 80 personas, con edades entre 21 y 83 años $(M=55,92, D P=12,06)$, que respondieron a un cuestionario bio-sociodemográfico y Técnica de Asociación Libre de Palabras. Los datos fueron computados por los softwares SPSS - 19.0 y Tri-Deux-Mots y examinados por medio de estadística descriptiva y análisis factorial de correspondencia. Los resultados señalaron que la construcción del conocimiento psico-sociólogico sobre la diabetes no difiere del saber científico, pues fue representada como enfermedad crónica relacionada con problemas de azúcar en la sangre, cambios de humor y peligro de vida. Las RS de tratamiento, surgieron de forma asociada al control de alimentos, manutención y adhesión a las orientaciones médicas. Se espera que esos resultados contribuyan para una mayor visibilidad de la enfermedad y con la elaboracción de prácticas terapéuticas en el contexto de la diabetes, dirigidas tanto a sus aspectos físicos como emocionales. Palabras-clave: Diabetes Mellitus; Representación Social; Psicosocial; Asociación Libre.
\end{abstract}

\section{Introduction}

Ever since the discovery of diabetes, a large number of researches have been carried out in several areas of knowledge, especially in the field of health (Stuhler, 2012; Biasi, 2011). Nowadays, it is a disease of great impact, as it is considered a public health problem for both emerging countries, and more developed ones. This comes about from its high prevalence and disabling complications that compromise productivity, quality of life and survival of people; also involving high costs due to its treatment (Stuhler, 2012).

Diabetes Mellitus (DM) is a chronic disorder, brought on by the absolute or relative deficiency in the secretion and/or action of insulin; which provokes in the organism the accumulation of glucose (sugar) in the bloodstream. The main reasons that contribute for its inception are associated with heredity/genetics, environment, sedentariness, inappropriate eating habits and obesity (International Diabetes Federation - IDF, 2015). 
The disease arises and progresses silently, comprising a heterogeneous set of metabolic dysfunctions associated with complications and failure of several organs; which more specifically affects the systems: ophthalmic, renal, neurological and cardiovascular (Rodríguez, Meneses, Toboso, \& Moreno, 2012; Brasil, 2006).

When it comes to psychosocial aspects, literature states that the social and professional spheres are also compromised. According to Barsaglini and Canesqui (2010), diabetic people feel uncomfortable when they need to participate in festivities, as the food that is appreciated and shared during these moments is caloric and sugar-filled. In summary, nourishment is the aspect that is most impacted in a diabetic person's life, as the comprehension on how hunger must be sated is developed based on cultural, social, economic and historical ideas. Eating is a basic necessity of the human being, but it is also a social act. How much, what, when, how, where and with whom you eat, as well as the prescriptions and proscriptions for food; are all determined by culture (Ribas, Santos, \& Zanetti, 2011).

Moving onto the professional sphere, a study carried out by Silva (2012) stated that the presence of diabetes affects productivity and participation in the market, regardless of sex, making it so that these people reach lower yields compared to those who are healthy. Therefore, diabetes is a complicated and painful affliction that interferes in the lifestyle of the patient and their relatives, permeated by difficulties in living through routines and habits (Leal, Fialho, Dias, Nascimento, \& Arruda, 2012).

According to more recent estimates by International Diabetes Federation, there are approximately 415 million people in the world who have diabetes; it appears on the list of the five chronic non-contagious diseases with the highest mortality rate (IDF, 2015). In Brazil, about 14,3 million people carry the ailment and there are 500 new cases every day, thus, it is estimated that $50 \%$ of the population who have DM type 2 do not know about the diagnosis, only realizing so after complications start surfacing (Brasil, 2013).

According to the Brazilian Diabetes Association (BDA), knowledge surrounding the number of diabetic Brazilians is of utmost importance to comprehend the current situation of the population and, moreover, to plan the future, aiming to prevent new cases from coming about, as, although much has been attained when it comes to the pharmacological treatment, the degree of control over the disease still falls short compared to the optimal one (BDA, 2015). Therefore, it is imperative that studies be carried out aiming the prevention of this affliction, focusing not only on the pharmacological treatment, but also, simultaneously, on complementing the dietary reeducation and continuous physical activities.

It is also worth mentioning that the main goal of the treatment is to attain glucose control, the recommendation being up to $110 \mathrm{mg} / \mathrm{dL}$ fasting and around $150 \mathrm{mg} / \mathrm{dL}$ two hours after eating, according to BDA (BDA, 2015). Thus, treatment is anchored along with non-medicated and medicated measures. The former ones comprise the food plan where the diabetic individuals know the types of food, the amount and frequency that must be consumed, as well as the regularity of the physical activities. Not only that, it is essential that the patients go through an educational program that will allow greater knowledge acquirement focused on selfcare and handling the disease.

Attaining these abilities is considered an effective strategy to strengthen motivation to continue the food plan, increase in the physical activities, self-care relating to the feet, regular execution of the capillary blood glucose test at home, prevention of episodes of hypoglycemia and chronic complications, as well as the care in special situations (Landim, Zanetti, Santos, Andrade, \& Teixeira, 2011).

Regarding the medicated measures, they aim to control sugar levels in the bloodstream avoiding spikes of hypoglycemia or hyperglycemia, they are indicated for patients who could not do so through non-medicated paths. Included here are drugs and insulin. In summary, treatment for diabetes must be embedded into the threefold that consists of drugs, nourishment and continuous practice of physical activities. According to Costa and Coutinho (2016), it is possible to verify that diabetic people are responsible for a well-maintained treatment, keeping in mind the consequences of the ailment.

Also, knowing the conception people who suffer from diabetes have about the disease and its treatment may contribute for a greater visibility of the phenomenon and, thus, for how to behave in face of it. To achieve such goals, for this study, it was utilized a theoretical contribution of Social Representations (SR), since studying the phenomenon of diabetes mellitus like this allows the construction of a practical knowledge socially elaborated and shared with a common group, who corroborates to the construction of a reality similar to a social ensemble (Jodelet, 2011). 


\begin{abstract}
According to Moscovici (2012), social representations must be viewed as a specific way to comprehend and communicate what we already know. They occupy, effectively, a curious position, somewhere among concepts, that have as their goal to abstract any sense from the world to insert in it order and perception; which will end up reproducing the world in a more meaningful way (p.46).
\end{abstract}

Accordingly, identifying social representations from the participants who have diabetes mellitus will allow the comprehension of how these individuals interpret or explain this new life, including their thoughts, feelings, conduct and future expectations in face of the disease. According to Moscovici (1978), from a tridimensional perspective, SR take into account three basic dimensions: information, field of representation or image and attitude.

"Information" or "Conceptual dimension" refers to organization and amount of knowledge that a certain group to which one belongs (diabetic patients) has about the affliction (diabetes); which are disseminated through conversations and by the media (Moscovici, 2012; Sá, 1998). "Field of representation or image" emerges from a dynamic introduction, unifying internal conflicts and, also, namely, the ones that emerge from perceptions and concepts. The role attributed to the image selects a title, instead of SR, which works as metonymy to a model that comprises the other dimensions; information and attitude, from which subjects can be differentiated, be them individuals or groups that produce them (Jesuíno, 2013). About the third dimension, "attitude" refers to the individual's global orientation or group to which they belong in accordance to the object of the SR; thus, people might have a favorable or unfavorable opinion about the new element to be classified and named (Moscovici, 1978).

From a psychosocial perspective, studies that cover different ways to identify SR are observed inside a diabetic context, for instance, the SR from basic health care were studied by Amorim, Ramos, Brito and Gazzinelli (2014), as well as the relationship of the process for health and disease that were identified by the authors LeClair, Marquis, Villalon and Strychar (2009) and Péres, Franco, Santos and Zanetti (2008). Others, in their own time, developed researches focused on the treatment, as it was the case for Stuhler (2012), and about the nutritional orientations analyzed by Biasi (2011), Ribas, et al. (2011), Barsaglini and Canesqui (2010). Besides, Mantovani, Fegonesi, Pelai, Saviane Pagotto (2013) and Coelho, Silva and Padilha (2009) comprehended SR regarding the diabetic foot, the same way that other authors studied the service provided by health professionals and about family support noticed during treatment (Ribas, Santos, Zanetti, \& Zanetti, 2013; Santos et al., 2011).

Even with the aforementioned studies, available literature anchored in a psycho-sociological approach on diabetes and elaborated by people with the disease is scarce, being more frequent in Nursing and Anthropology, with little to no emphasis on Psychology (Ribas et al., 2013; Stuhler, 2012).

In such a way, it is necessary to develop studies that cover what this ailment represents to men and society as a whole, as well as to identify possibilities to change concepts and attitudes related to it; which justifies the construction of new researches that focus on comprehension and elaboration of a process of social construction for people who have diabetes. So, this article has as its objective to analyse social representations, developed by diabetic people, about diabetes mellitus, using semantic fields that come from the evocation to inducting stimuli: diabetes, treatment and one's own self.

\section{Method}

\section{Type of study}

This is a research from a descriptive field that has a transversal nature, having qualitative and quantitative characteristics, subsidized on a psycho-sociological approach.

\section{Participants}

This study is presented with a probabilistictype sampling, for convenience and snowball. It was adopted as inclusive criteria: (i) being of the age of 18 years old or over and (ii) having the diagnostic of DM. The sampling was constituted of 80 participants, ages varying between 21 and 83 years old $(A=55,92$; $\mathrm{SD}=12,06)$.

Among the interviewed, the majority (81\%) was female, 55\% married, 55\% finished middle school and $31 \%$ high school, $62 \%$ catholic, those who plied different kinds of trades were 55\% (e.g. teachers, maids, vendors and nursing technicians), $82 \%$ with an income up to minimal wage. The time since diagnosis varied from 1 to 36 years $(A=10,51 ; S D=8,5)$, where the majority, (60\%) from 1 to 10 years and 30\% from 11 to 20 years, the rest had over 21 years since diagnosis. DM type 2 was the most prevalent, adding up to $95 \%$ of the 
participants, although $57 \%$ of them affirmed they did not make use of insulin.

\section{Instruments}

To obtain the data, a biosocial-demographic questionnaire was utilized along with a Word Association Test (WAT). The former was used aiming to obtain information such as age, sex and marital status, time being treated, use of insulin, and others, making up the characteristic profile of the sample.

WAT was used having as inducting stimuli: "diabetes", "treatment" and "one's own self". This instrument is a projective technique and does not have psychometric properties, being originally developed by Jung in the beginning of the $20^{\text {th }}$ century to be clinically utilized; which was later adapted by Giácomo, in 1981, as a research tool in Social Psychology. Currently, WAT is widely utilized, mainly when working for the theoretical contributions of SR; which allows the highlight of semantic universes that reflect on the regular universes of words in face of different stimuli and subjects or groups, allowing the identification of latent elements that would be masked in discursive productions (Coutinho \& Do Bú, 2017).

\section{Ethical procedure}

The research was approved by the Committee of Ethics in Research of the Universidade Federal da Paraíba, under the protocol n. 914.880 and CAAE (Certificate of Presentation for Ethical Appreciation) n. 33087214.6.0000.5188. For its execution, all ethical conditions were respected; they were established by the Commission of Health National Council, created by Resolution 466/2012 and constitution designed by Resolution 246/97.

\section{Procedure and Data analysis}

Regarding the procedure for data collection, it is highlighted that the research was carried out in clinics that offered medical assistance for diabetic individuals, thus, after consent, patients were approached both while waiting for their medical consultation, and in other convenient places and times for them. Initially, each patient signed an Informed Consent Form and, subsequently, the instrument administration was performed, abiding by the following order: first, WAT; then, biosocial-demographic questionnaire. The instruments were applied individually and orally, being read by researchers. The average time for application was 25 minutes.
Data that originated from the biosocial-demographic questionnaire were processed using the Statistical Package for the Social Sciences (SPSS - 19.0) and were analysed according to descriptive statistics (average, standard deviation and frequencies). Data coming from WAT were implemented using the software Tri-Deux-Mots (version 2.2) though, following the standard procedure; which consists of five stages: IMPMOT (generation of the dictionary and the absolute frequency of words), TABMOT (making of data tabulation), ECAPEM (crossover between fixed and opinion variables, resulting in how each modality will cooperate to construct the factor), ANECAR (generation of the file that bears the greatest contributions to construct the graph, in which position they are found on the factorial plan and how they are articulated in accordance to the inclusion and exclusion relating to the qui-square calculation) and PLANFA (production of the graph with the coordinates and the factors). Afterwards, data were analysed by Correspondence Factor Analysis (CFA). Attention must be drawn to this procedure's methodological importance, as it allows graphical representation of approximation and divergence among the fixed variables: sex, marital status, insulin use and time until diagnosis; and the opinion variables on the inducting stimuli: diabetes, treatment and one's own self (Coutinho \& Do Bú, 2017).

\section{Results and Discussion}

The results of the 792 words that came from WAT, after processing by Tri-Deux-Mots, pointed to 264 different words and, among these, 66 were used to construct the factorial plan. According to the relative distribution of each word in the factorial space, the explanative power was of $52.0 \%$ (total variance), that was distributed to F1 (29.7\%) and F2 (22.3\%) (Figure 1), thus showing statistical parameters that have internal consistency and reliability, considering researches carried out for the RS (Coutinho \& Do Bú, 2017).

For Factor 1 (F1), horizontal line in bold, from the factorial plan, the constructions regarding sex were observed. On the left side, evocations from the women relating to their first inducting stimulus, "diabetes", can be found. For them, "disease" and "being ill" were represented in an indistinguishable way, the former being addressed by the word "foot"; the latter, by the elements " not eating what one likes" and "sad", anchored in the physiological, nutritional and psycho-affective spheres, respectively.

Psico-USF, Bragança Paulista, v. 23, n. 2, p. 191-201, abr./jun. 2018 


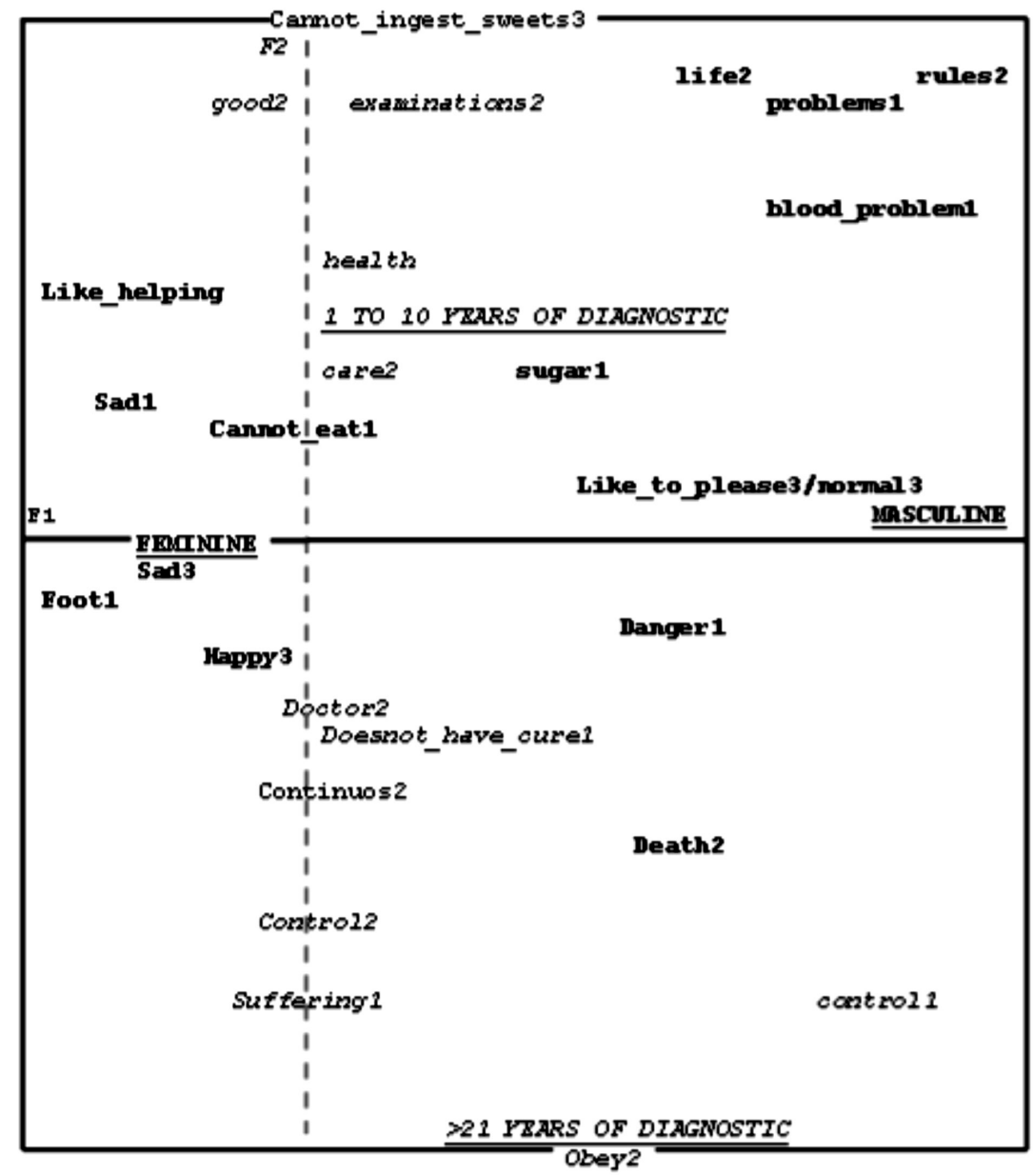

Factor 1 (F1), in bold, is located on the horizontal axis on the right and on the left.

Factor 2 (F2), in italics, is located on the upper and lower vertical axis.

Fixed variables: Sex and time of diagnosis.

Inducing stimuli: 1 = diabetes; 2 = treatment and $3=$ one's own self.

Figure 1. Correspondence Factorial Plan of the SR on diabetes.

As observed, the female participants of the study supposedly showed relative preoccupation with the health and appearance of their lower limbs. It is inferred that this group represented the foot as a warning sign for the diabetic person, as it may facilitate circulatory alterations, infections and ulcers. These results are in conformity with literature; which preconizes that negligence regarding this specific part of the body might lead to a macro-vascular complication that causes the destruction of the feet's deep tissues, linked to neurological abnormalities and amputation for more severe instances of the disease (Parisi, 2015). For the studies developed by Mantovani et al. (2013) and Coelho et al. (2009), it was noted that the affliction might propel the subjects to preventive attitudes in the sense of life preservation, as well as a feeling of guilt when being negligent in not caring for their health.

Regarding the second indication, "not eating what one likes", it is observed that the nutritional matter is an essential factor for the new lifestyle. However, change in food education goes through some hindrances, as is the case for habits acquired and cemented throughout their lives, lack of support from their families, the belief that satiation is connected to how much and not how well they eat, among others. These limitations that come about because of the ailment and its treatment 
minimize the options for different dietary styles; this is also true for other factors that involve the treatment, such as glucose control, insulin use and routine use of several medications.

These results harmonize with literature on the subject when it states that poor food habits are risk factors to contract diabetes, and they are also the main villains after the settlement of the affliction (Rodríguez et al., 2012; Simões, 2012).

Moving onto the third indication, "sad", it probably comes from receiving the diagnosis which leads to emotional frailty, as it is a chronic disease that requires continuous treatment. Studies carried out by Costa and Coutinho (2016) and Ferreira, Daher, Teixeira and Rocha (2013) also confirm emotional repercussions in diabetic patients linked to sadness, depression, crying, suffering, desolation, insecurity; all of which may interfere directly in living with the disease. It is suggested that the carriers of this syndrome have psychotherapeutic assistance; which contributes to better acceptance of the affliction and administration of the therapeutic itinerary.

In general, it can be said that the representational field (not eating what one likes, caring for the feet and feeling sad) built by the participants of the study was similar to the scientific knowledge. This construction is probably true due to the tridimensionality of RS; which are connected to "information" or "conceptual dimension" which a certain group to which one belongs (diabetic women) has about the disease, be it by the conversations and/or the means of communication that are present in daily life. The construction also points to "field of representation" or "image" as a unifier of internal conflicts, being inferred the positioning of "attitudes" when dealing with the disease as well.

Moving onto the stimulus "treatment", no evocations were observed in the factorial plan; which is probably due to the fact that there is little occurrence of it, according to the records of the subprogram ANECAR (Tri-Deux-Mots). Regarding the inducting stimulus "one's own self", the participants described themselves as people who "like to help", "sad and joyful", making up a semantic field anchored in social and psycho-affective categories. The first expression demonstrates that the fact that they are carriers of diabetes does not impede them from helping others; although the elements sad/joyful point to a possible unbalanced emotional state with which people with diabetes live.
Still about F1, on the right side, there is the semantic field made up by the male participants. To them, "diabetes" was characterized as "blood problem", "sugar", "danger" and "problems", anchored in biomedicine, nutrition and psycho-sociality.

It is observed that these participants backed up their knowledge on diabetes with scientific information, when they associate it with blood problems, change in sugar levels, having as the main symptoms physiological manifestations, being imperative that measures be adopted for sugar monitoring in the bloodstream and insulin injection. These results are in accordance with other studies, taking Simões (2012), LeClair, Marquis, Villalon and Strychar (2009) and Torres-López et al. (2005) as examples.

The second inducting stimulus, "treatment, was characterized by the elements "life", "death" and "rules", anchored in the bio-psychosocial sphere. As it was observed, the two first associations refer to an antagonistic situation (life/death) and the third one corresponds to necessary norms to fulfil treatment (ingestion of medicine, dietary re-education and physical activities). Therefore, it can be inferred that the approximation and distancing of life and death come from wanting and completing the treatment in its entirety.

Adhering to the treatment revolves around abiding to rules that were pre-established by the medical team, what is seen as ambivalent, because, as evidenced in the work of Péres et al. (2008), medication use is a resource that promotes well-being and quality of life improvement, but it is not always possible to do it properly. Insulin, as part of treatment, was considered effective due to its rapid effect and to the possibility of avoiding complications, although its use is linked to dysphoric feelings. Still about the thought of these authors, the negative representation of health services interferes in how one feels about adhering to the treatment with drugs. In other study developed by Ribas (2009) referring to the food plan, results pointed to food being identified paradoxically as something linked to desire and repulse, leading the diabetic patients to emotional wear and difficulties to achieve metabolic control.

Regarding physical activities, it is indicated to assist the diabetic treatment, as its practice leads to weight loss, improvement in sugar control, physical conditioning and improved self-esteem (Mendes, Dias, Gama, Castelo-Branco, \& Themudo-Barata, 2013). However, in the study of Barsaglini (2011), physical activities were regarded as limiting due to matters such as financial 
resources, time, physical limitations, old age, disbelief in their effects, lack of companionship, substitution for domestic activities and discomfort.

As for the third stimulus, "one's own self", men defined themselves using the following: "people who like to please" and "normal"; which are anchored in social relations. They refer to the notion that people with diabetes are considered normal beings, who like to help others; in this case, the affliction does not take from these men the perspective to see themselves as normal, as they can perform a number of activities. Similar results were found by Amorin et al. (2014), when they affirmed that changes and adaptations required by the treatment go through a process of normalization, while becoming part of the daily routine.

For the second factor (F2), vertical axis from the factorial plan, the collective thought of the participants is linked to time since diagnosis. On the upper part of the graph, evocations from the participants with a diagnosis between 1 and 10 years are present. These people did not provide enough evocations to the stimulus "diabetes", hence the lack of observations in the factorial plan, according to records from the subprogram ANECAR (Tri-deux-Mots).

Moving onto the second inducting stimulus, "treatment", participants from the group with diagnosis between 1 and 10 years recognized it as being "good", demanding "care", being submitted to "examinations" in order to have good "health". This representational field is anchored in bio-psychosocial and behavioural categories.

These participants showed preoccupation with maintaining good health when they understood treatment as something positive, thus, such aspect propels them to adopt measures to take care and prevent complications that might come from the ailment. Rodrigues et al. (2012) add up to that saying the desire to be part of or interrupt the treatment is connected to positive or negative attitudes when in face of diabetes.

Regarding the second inducting stimulus, "one's own self", these participants defined themselves as people who "cannot ingest sweets", highlighting the food restrictions that are necessary, as sugar changes glucose levels. This is also anchored in the nutritional category: it is known that excess sugar creates an unnecessary amount of energy in the organism, making it so that the pancreas produce insulin that is beyond necessary, leading to increase in weight which may cause obesity. The dimension of eating goes beyond simply ingesting food and must be seen intertwining with the biological prism. Thus, it comprises a complex system of values and meanings, encompassing its biological sociocultural, environmental, psychological and economical aspects (Barsaglini, 2011).

Other studies found that the representations of food may be filed under many meanings, such as loss of pleasure when eating and drinking, loss of self-esteem and freedom of choice for the desired food, food does not keep one up and lacks flavour, or is linked to quantity (not quality) (Ribas et al., 2011; Péres et al., 2008).

Still for the axis F2, on the lower part of the graph, elucidations from the participants who have a diagnosis that is over 21 years are situated. For the first inducting stimulus, "diabetes", it was linked to the elements "does not have a cure", "control" and "suffering", being anchored in the biomedical and psycho-affective spheres, respectively. These participants understand diabetes as a chronic disease when they report that it has no cure, requires control for the sugar levels and causes suffering. Thus, the individual must adapt to their new lifestyles, as it is necessary the introduction of therapeutic practices, change in dietary patterns, glucose control, medication injection, practice of physical activities, maintenance of blood pressure and monitoring by the multidisciplinary health team. Similar results were found by Oliveira and Vencio (2014), Tavares, Barreto, Lodetti, Guerreiro, Silva and Lessmann (2011) and Oliveira (2006).

The second inducting stimulus, "treatment", was characterized by "doctor", "continuous", "control" and "obedience", taking into account that this representational field is anchored on the biomedical sphere. It is possible to infer that the participants who have longer time since diagnosis refer to the behavior that must be adopted when facing the disease, in this case, because it is a chronic disease, connected to the need of a continuous medical treatment that requires control and obedience.

These results are in accordance with the ones from Marcelino and Carvalho (2005), when they affirm that there are cases in which it is necessary to bear in mind the importance of the control and obedience to the treatment. For these authors, it is not enough to understand the disease and its consequences, as the physical affliction also encompasses the psychological sphere, because the former comprises elements that might lay in unawareness. This assumption alludes to the RS mute zone when Abric (2003) states the existence of elements that are masked or hidden in the 
representative dimensions; which, although shared by members of a group to which one belongs (diabetic patients), they rarely surface.

When it comes to the third inducting stimulus, "one's own self", the evocations were not enough to be present on the factorial plan, according to the registrations from the subprogram PLANFA (Tri-Deux-Mots). In general, the semantic field of social representations on diabetes and its treatment is anchored in different spheres that go from the biomedical, physical, behavioral, and social to the psycho-affective, highlighting the complexity and multiplicity of the phenomenon.

\section{Final Considerations}

This study aimed to analyse social representations drawn up by diabetic people about diabetes mellitus, its treatment and one's own self. The findings from this research accentuated that the social representation for diabetes was built, following scientific knowledge's example, as a chronic disease related to problems with sugar in the bloodstream, representing danger in the lives of those who suffer from the disease. Regarding the treatment, it was observed representations for awareness of the importance of adhering to it, linked to medicine ingestion and dietary control. However, no mention to the practice of physical activities was made; which is also vital to the treatment.

It was detected that female participants characterized the disease associated with food restrictions, mood swings and referral to the foot as the most worrisome limb, whereas men built representations connected with a more concrete basis when they associate diabetes with blood problems, risk of death and obedience to the rules of the treatment.

Participants, regardless of sex, with less time since diagnosis, developed their representations focusing on the positive aspects of treatment, regarding it as something good; which demands care and regular examinations in order to maintain good health. On the other hand, participants with longer time since diagnosis concentrated their representations on the negative side of the disease and its treatment, conveying the possibility that there will never be a cure, continuity and control to obey medical recommendations, leading to a life of suffering.

Analyses of the participants' social representations from this study were of great importance in the sense that they allowed better understanding of the disease and its treatment. With that in mind, results pointed to the importance of a multidisciplinary approach, focused on psycho-sociology; which aims to tackle clarification on the causes and consequences of the affliction, as well as practices to incentive physical activities.

It is worth mentioning that the current study points as a limitation the impossibility to generalize results with other samplings, as these findings allude to a specific group of diabetic people, located in an exclusive context. It can also be pointed, as a limitation, the exclusive use of a single instrument in order to apprehend social representations. Albeit such limitations do not invalidate the previously described findings that, in general, demonstrated that, beyond physiological and social implications, the diabetic patient needs more attention regarding the psychological scope, as mood swings may interfere with treatment and lifestyle.

When it comes to applicability of this study, it is hoped that these results may pave the way for future investigations. Thus, studies that focus on the process of resiliency, quality of life and subjective wellbeing are necessary; aiming to envision how the group overcomes adversities that are spawned from its context. Not only that, but it is also relevant to point to the importance of other studies that take into consideration the apprehension to adhere to the treatment, aiming to the adoption of other strategies to control and take care of the disease.

\section{References}

Abric, J. C. (2003). L`analyse structurale des représentations sociales. Em S. Moscovici, \& F. Bushinni (Eds.), Les Méthodes des Sciences Humaines (pp. 375392). Paris: Presses Universitaires de France.

American Diabetes Association [ADA]. (2016). Diabetes mellitus. Recuperado em http://www.diabetes.org/ are-you-at-risk/prediabetes $/$ ?loc $=$ superfooter

Amorim, M. M. A., Ramos, N., Brito, M. J. M., \& Gazzinelli, M. F. (2014). Identity Representations of People with Diabetes. Qualitative Health Research, 24, 913-922. doi: http://dx.doi. org/10.1177/1049732314539577

Barsaglini, R. A. (2011). Representações sociais e a experiência com o diabetes: um enfoque socioantropológico. Rio de Janeiro: Editora Fiocruz.

Barsaglini, R. A., \& Canesqui, A. M. (2010). A alimentação e a dieta alimentar no gerenciamento da 
condição crônica do diabetes. Saúde e Sociedade, 19(4), 919-932. doi: http://dx.doi.org/10.1590/ S0104-12902010000400018

Biasi, J. B. (2011). Representação social dos portadores de diabete acerca das orientacõoes nutricionais prestadas pela equipe de saúde da família. (Trabalho de Conclusão de Curso). Universidade do Sul de Santa Catarina, Florianópolis, Santa Catarina.

Brasil. Ministério da Saúde (2013). Secretaria de Atenção à Saúde. Departamento de Atenção Básica. Estratégias para o cuidado da pessoa com doença crônica: diabetes mellitus. Brasília (DF).

Brasil. Ministério da Saúde. (2011). Plano de ações estratégicas para o enfrentamento das doenças crônicas não transmissíveis (DCNT) no Brasil 2011-2022. Secretaria de Vigilância em Saúde. Departamento de Análise de Situação de Saúde. Brasília (DF).

Coelho, C. R., \& Amaral, V. L. A. R. (2008). Análise de contingencias de um portador de diabetes mellitus tipo 2: estudo de caso. Revista de Psicologia da Universidade São Francisco, 13(2), 243-251. doi: http:// dx.doi.org/10.1590/S1413-82712008000200011

Coelho, M. S., Silva, D. M. G. V., \& Padilha, M. I. S. (2009). Representações sociais do pé diabético para pessoas com diabetes mellitus tipo 2. Revista Escola de Enfermagem da Universidade de São Paulo, 43(1), 65-71. doi: http:// dx.doi.org/10.1590/S0080-62342009000100008

Costa, F. G., \& Coutinho, M. P. L. (2016). Representações sociais no contexto do diabetes mellitus. Psicologia em Estudo, 21(1), 175- 185. doi: http:// dx.doi.org/10.4025/psicolestud.v21i1.29792

Coutinho, M. P. L. (2005). Depressão infantil e representações sociais. ( $2^{\mathrm{a}}$ ed). João Pessoa: Editora Universitária/ UFPB.

Coutinho, M. P. L., \& Do Bú, E. A. (2017). A técnica de associação livre de palavras sobre o prisma do software tri-deux-mots (version 5.2). Revista Campo do Saber, 3(1), 219-243. Retrivied from http:// periodicos.iesp.edu.br/index.php/campodosaber/ article/view/72/58

Denisco, S. (2011), Exploring the relationship between resilience and diabetes outcomes in African Americans. Journal of the American Academy of Nurse Practitioners, 23, 602-610. doi: http:// dx.10.1111/j.1745-7599.2011.00648.x
Ferreira, D. S. P., Daher, D. V., Teixeira, \& E. R., Rocha, I. J. (2013). Repercussão emocional diante do diagnóstico de diabetes mellitus tipo 2. Revista de Enfermagem da Universidade do Rio de Janeiro, 21(1), 41-46.

Internacional Diabetes Federation [IDF] (2015). Diabetes mellitus. Recuperado em: http://www.idf.org

Jesuíno, J, C. (2013). Estruturas e processos grupais. Em J. Vala \& M. B. Monteiro (Eds.), Psicologia social. ( $9^{a}$ ed., pp. 293- 332). Lisboa: Fundação Calouste Gulbenkian.

Jodelet, D. (2011). Representações Sociais: Um domínio em expansão. Em D. Jodelet (Eds.), As Representações Sociais. (pp. 17-44). Rio de Janeiro, RJ: UERJ.

Landim, C. A. P., Zanetti, M. L., Santos, M., A., Andrade, T. A. M., \& Teixeira, C. R. S. (2011). Self-care competence in the case of Brazilian patients with diabetes mellitus in a multiprofessional educational programme. Journal of Clinical Nursing, 20(23-24), 3394-3403. doi: http:/ / dx.10.1111/j.1365-2702.2011.03883.x

Leal, D. T., Fialho, F. A., Dias, I. M. A., Nascimento, L., \& Arruda, W. C. (2012). A vivência dos familiares de crianças e adolescentes portadores de diabetes mellitus tipo 1. Revista Eletrônica de Enfermagem. 14(1), 189- 196. Retrieved from http://www.fen. ufg.br/revista/v14/n1/v14n1a22.htm.

LeClair, C., Marquis, M., Villalon, L., \& Strychar, I. (2009). Healthy adolescents' social representations of diabetes. Canadian Journal of Diabetes, 33(3), 170- 179. doi: http://dx.doi.org/10.1016/ S1499-2671(09)33008-7

Mantovani, A. M., Fegonesi, C. E. P. T., Pelai, E. B., Savian, N. U., \& Pagotto, P. (2013). Estudo comparativo das representações sociais sobre diabetes mellitus e pé diabético. Cadernos em Saúde Pública, 29(12), 2427-2435. doi: http://dx.doi. org/10.1590/0102-311X00006613

Marcelino, D. B., \& Carvalho, M. D. B. (2005). Reflexões sobre o diabetes tipo 1 e sua relação com o emocional. Psicologia: Reflexão e Crítica, 18(1), 72-77. Retrieved from http://www.scielo.br/pdf/\%0D/ $\mathrm{prc} / \mathrm{v} 18 \mathrm{n} 1 / 24819 . \mathrm{pdf}$.

Mendes, R., Dias, E., Gama, A., Castelo-Branco, M., \& Themudo-Barata, J. L. (2013). Prática de exercício físico e níveis de atividade física habitual em 
doentes com diabetes tipo 2- estudo piloto em Portugal. Revista Portuguesa de Endocrinologia, Diabetes e Metabolismo, 8(1), 9-15. doi: http://dx.10.1016/j. rpedm.2012.05.001

Moscovici, S. (1978). A representação social da psicanálise. (A. Cabral, Trad.). Rio de Janeiro, RJ: Zahar editores.

Moscovici, S. (2012). Representações sociais: Investigacõoes em psicologia social ( $7^{\mathrm{a}}$ ed.). Petrópolis, RJ: Vozes.

Nóbrega, S. M., \& Coutinho, M. P. L. (2011). O teste de associação livre de palavras. Em M. P. L. Coutinho \& E. R. A. Saraiva (Eds.), Métodos de pesquisa em psicologia social:perspectivas qualitativas e quantitativas. (pp. 95-147). João Pessoa, Editora Universitária.

Oliveira, J. E. P., \& Vencio, S. (2014). Diretrizes da Sociedade Brasileira de Diabetes: 2013-2014/ Sociedade Brasileira de Diabetes. São Paulo: AC Farmacêutica.

Parisi, M. C. R. (2015). A síndrome do pé diabético, fisiologia e aspectos práticos. Em M. Tambascia, W. J. Minicucci \& A. P. Netto (Eds.), E-Book 2.0Diabetes na Prática Clínica. Sociedade Brasileira de Diabetes. Retrieved from http://ebook.diabetes. org.br

Péres, D. S., Franco, L. J., Santos, M. A., \& Zanetti, M. L. (2008). Representações sociais de mulheres diabéticas, de camadas populares, em Relação ao processo saúde-doença. Revista Latino-americana de Enfermagem, 16(3). Retrieved from http://www. scielo.br/pdf/rlae/v16n3/pt_09.pdf

Ribas, C. R. P. (2009). Representações sociais dos alimentos para pessoas com diabetes mellitus tipo 2. (Dissertação de mestrado). Escola de Enfermagem de Ribeirão Preto da Universidade de São Paulo, São Paulo.

Ribas, C. R. P., Santos, M. A., \& Zanetti, M. L. (2011). Representações sociais dos alimentos sob a ótica de pessoas com diabetes mellitus. Revista Interamericana de Psicologia, 45(2), 255-262. Retrieved from http:// www.redalyc.org/articulo.oa?id $=28422741016$

Ribas, C. R., Santos, M. A., Zanetti, A. C. G., \& Zanetti, M. L. (2013). Representações sociais de pacientes com diabetes mellitus sobre o atendimento por profissionais de saúde. PSICO, 44(1), 139-149.

Rodrigues, F. F, L., Santos, M. A., Teixeira, C. R. S., Gonela, J. T., \& Zanetti, M. L. (2012). Relação entre conhecimento, atitude, escolaridade e tempo de doença em indivíduos com diabetes mellitus.
Acta Paulista de Enfermagem,25(2), 284-90. Retrieved from http://www.scielo.br/pdf/ape/v25n2/ a20v25n2.pdf

Rodríguez, S. A., Meneses, L., Toboso, R. P. Q., \& Moreno, I. H. (2012). Diabetes mellitus. Medicine, 11(17), 995-1002. doi: 10.1016/ S0304-5412(12)70418-3

Sá, C. P. (1998). A construção do objeto de pesquisa em representações sociais. Rio de Janeiro, RJ: UERJ.

Santos, M. A., Alves, R. C. P., Oliveira, V. A., Ribas, C. R. P., Teixeira, C. R. S., \& Zanetti, M. L. (2011). Representações sociais de pessoas com diabetes acerca do apoio familiar percebido em relação ao tratamento. Revista da Escola de Enfermagem da Universidade de São Paulo, 45(3), 651-658. doi: http:// dx.doi.org/10.1590/S0080-62342011000300015

Silva, I. K. (2012). Perdas de rendimento dos portadores de diabetes Mellitus: uma análise contra-factual, Brasil, 2008. (Dissertação de Mestrado). Universidade Católica do Rio Grande do Sul, Porto Alegre, Rio Grande do Sul.

Simões, W. A. (2012). Concepcões e práticas de mulheres portadoras de diabetes mellitus no contexto da atenção primária à saúde. (Dissertação de mestrado). Universidade Federal do Rio Grande do Sul.

Sociedade Brasileira de Diabetes. (2015). Diretrizes da Sociedade Brasileira de Diabetes. ( $3^{a}$ ed.). Itapevi, SP: A. Araújo Silva Farmacêutica.

Stuhler, G. D. (2012). Representacões sociais e adesão ao tratamento do diabetes mellitus tipo 2. (Tese de Doutorado). Universidade Federal de Santa Catarina. Florianópolis, Santa Catarina.

Tavares, B. C., Barreto, F. A., Lodetti, M. R., Guerreiro, D. M., Silva, V., \& Lessmann, J. C. (2011). Resiliência de pessoas com diabetes mellitus. Texto Contexto de Enfermagem, 20(4), p. 751-757. Retrieved from http://www.redalyc.org/articulo. oa?id $=71421162014$

Torres-López, T. M., \& Sandoval-Díaz, M. (2005). "Sangre y azúcar": representaciones sobre la diabetes de los enfermos crónicos en un barrio de Guadalajara, México. Caderno de Saúde Pública, 21(1), 101-110. Retrieved from http://www.scielo. $\mathrm{br} / \mathrm{pdf} / \mathrm{csp} / \mathrm{v} 21 \mathrm{n} 1 / 12 . \mathrm{pdf}$

Recebido em: 05/09/2016

Reformulado em: 03/04/2017

Aprovado em: 15/05/2017 
Sobre as autoras:

Fabrycianne Gonçalves Costa is a Neuropsychologist and $\mathrm{PhD}$ in Social Psychology from the Federal University of Paraíba, member of the Research Center for Psychosocial Aspects of Prevention and Collective Health.

E-mail: fabrycianne@gmail.com

Maria da Penha de Lima Coutinho has a PhD in Clinical Psychology from the University of São Paulo and a Postdoctorate from the Universidade Aberta de Lisboa, Portugal. Coordinator of the Psychology course at the Higher Education Institute of Paraíba and the Research Center for Psychosocial Aspects of Prevention and Collective Health at the Federal University of Paraíba.

E-mail: mplcoutinho@gmail.com

\section{Contato com as autoras:}

Fabrycianne Gonçalves Costa

Rua Maria Helena Rocha, 113, aparto 1301- Bl. A, Aeroclube

João Pessoa-PB, Brasil

CEP: 58036-823 